
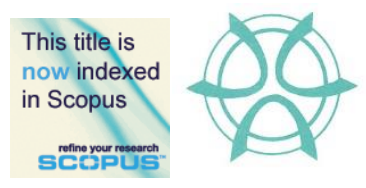

PLANNING MALAYSIA:

Journal of the Malaysian Institute of Planners

VOLUME 15 ISSUE 1 (2017), Page 89 - 108

\title{
COMMUNITY-BASED TOURISM IN MELAKA UNESCO WORLD HERITAGE AREA: A SUCCESS IN FOOD AND BEVERAGE SECTOR?
}

\author{
Syakir Amir ${ }^{1}$, Mariana Mohamed Osman², Syahriah Bachok ${ }^{3}$, Mansor Ibrahim ${ }^{4}$, \\ \& Ismawi Zen ${ }^{5}$ \\ ${ }^{1,2,3,4,5}$ Kulliyyah of Architecture and Environmental Design \\ INTERNATIONAL ISLAMIC UNIVERSITY MALAYSIA
}

\begin{abstract}
Community-based Tourism (CBT) is a tool for local economic development due to its capability and strength to provide economic sources to the resident destination. Given its focus on benefiting the local community, CBT has attracted a significant degree of academic attention. However, to date, there has been little discussion and evidence based on comprehensive studies on local economic benefits with regards to tourism activities in Malaysia as compared to other regions. This study examined tourists' expenditure on food and beverage, and its contribution to the local economic in Melaka UNESCO World Heritage area. A total of 1,000 diary record survey were collected. Chi-square Automatic Interaction Detection (CHAID) was used to model interaction of domestic and international tourists. The results revealed $22.1 \%$ of the tourists spent between RM16.00-RM147.50 per trip for breakfast, lunch and dinner. However, only $9 \%$ (breakfast), 34\% (lunch) and 43\% (dinner) were channelled to local economy.
\end{abstract}

Keyword: Tourists expenditure, food and beverage, Melaka UNESCO World Heritage area

Date Received: $30^{\text {th }}$ April 2016

Date of Acceptance: $30^{\text {th }}$ October 2016 
Syakir Amir, Mariana Mohamed Osman, Syahriah Bachok, Mansor Ibrahim, \& Ismawi Zen

Community-Based Tourism in Melaka UNESCO World Heritage Area: A Success in Food and Beverage Sector?

\section{INTRODUCTION}

Malaysia has been practising the community-based tourism (CBT) approach in tourism development since the year 2000 until the present. The communitybeneficial policies and strategies were introduced in the Eighth Malaysia Plan for the period of 2001-2005. The aspiration for community benefits was continued in the Ninth Malaysia Plan (2006-2010) and Tenth Malaysia Plan (2011-2015). The government has allocated around RM19 million to help generate income among the local community members involved in the tourism industry (Ministry of Tourism and Culture Malaysia, 2015). Community-based tourism programs that were considered successful in generating an influx of tourists were homestay programs in Kampung Bukit Bangkong, Kampung Hulu Chucoh and Kampung Hulu Teris in Banghuris, Selangor (Fauziah Che Leh \& Mohd Rezuan Hamzah, 2012). Many researchers have conducted studies on local participation in tourism activities such as Zaaijer and Sara (1993), Brandon (1996), Wells, (1996), Aas, Ladkin and Fletcher (2005), Jones (2005), Lepp (2007), and Lee (2012). However, to date, limited study has been done to assess and validate the economic benefits received by the local economy from the various tourism activities in an area and therefore, this research is timely. Melaka UNESCO World Heritage area was chosen as the study area as it has recorded the highest number of domestic and international tourist visits in addition to being inscribed by United Nations Educational, Scientific, and Cultural Organization (UNESCO) as a 'World Heritage Site'.

Tourism is an expenditure-driven economic activity (Mihalic, 2002), that often a significant source of income in many countries (Mok \& Iverson, 2000; Li, Song \& Witt, 2005; Song \& Li, 2008). Tourists purchasing pattern is likely to vary in several tourism activities namely in accommodation, entertainment, shopping, food and beverage as well as transportation (Wang, Rompf, Severt \& Peerapatdit, 2006). Moreover, tourist expenditure in those tourism activities is considered as one of the potential tools to improve the economy of local communities (Beeton, 2006; Trejos \& Chiang, 2009; Sutawa, 2012). Therefore, tourism is believed to be able to generate income and enhance the economic opportunities of the local community. However, more recently, literatures have emerged that offer different findings, where benefits from tourism activities are low to local economy (Crompton, Lee \& Shuster, 2001; Tyrrell \& Johnston, 2001; Kasimati, 2003; Daniels, Norman \& Henry, 2004). Therefore, community-based tourism should be encouraged to improve the economic benefits received by the local community in expanding their economic opportunities in the tourism industry.

The aim of this paper is to examine the local economic benefits from the food and beverage sector in Melaka UNESCO World Heritage area. 
PLANNING MALAYSIA

Journal of the Malaysia Institute of Planners (2017)

\section{LITERATURE REVIEW}

\section{Community-based Tourism}

Community-based tourism (CBT) is a type of sustainable tourism where 'people' or 'community' is the focus of tourism development in a particular host destination. Pearce and Moscardo (1999) believe that CBT can produce successful practice and implementation process in developing and less developed countries. This is supported by McCool, Moisey and Nickerson (2001), Davis and Morais (2004), Roe, Ashley, Page and Meyer, (2004) where their studies have observed the CBT in countries like Gambia, Uganda, Cambodia and Laos. McMillan and Chavis (1986) define the term 'community' into three categories (i) Ecological approach: the community living together and adapting to the setting, a process that produces distinctive community characteristics. (ii) Social approach: the roles and institutions that govern society, social relations and the primacy of group membership. (iii) Interactive approach: social interactions of individuals, people, organization occupying a restricted geographic area. As a result, these categories portray multiple descriptions and classifications of the term.

Kling and Posner (1990) have added the 'community' in ecological approach, as a group of people that share a similar geographical area, for instance, the community in a residential area or a village. Madrigal (1995) argues that a community living in the same geographical area can be categorized into smaller communities, such as the youth community, elderly community and housewife community that share common characteristics within the area.

Hollinshead (2004) divides the community into three groups, which are based on solidarity, geographic area and socio-geographic structure. Other scholars define 'community' as a group of people living and staying in the same locality, as well a group of people that share similar ideas, purposes and basic values (Davis, 1991: Mayer et al., 2000; Williams \& Lawson, 2001).

The clarification of 'community' is crucial for the study in order to justify the direction of community-based tourism. The definitions discussed mainly refer to spatial and interaction factors. This shows that communities are varied in nature. A community consists of various characteristics and attributes in the radius of large land uses and town centres along with types of tourism activity areas that consists of different community organizations, structures, relations and roles.

\section{Local Economic}

According to authors such as Bellamy, Meppem, Gorddard and Dawson (2003), Koo (2005), Shaffer, Deller and Marcouiller (2006), and Gunder (2009), there is no clear and hierarchal sequence of local economic theories in describing details of local economic development and benefits due to the complexity, flexibility and 
Syakir Amir, Mariana Mohamed Osman, Syahriah Bachok, Mansor Ibrahim, \& Ismawi Zen

Community-Based Tourism in Melaka UNESCO World Heritage Area: A Success in Food and Beverage Sector?

multiple perspectives influenced by mixed concepts (Rowe, 2009; 2012), practices (Valler \& Wood, 2010) and rhetoric (Scott, 2006). In addition, Gunder (2004) clarifies that the built environment field, especially in town and regional spatial planning, often face inconsistent and conflicting theoretical bases when dealing with local economic development. Most of the CBT describe high economic impacts and benefits of tourism activities which must be channelled to the host destination residents (Amat Ramsa Yaman \& Abdullah Mohd, 2004; Jones, 2005).

Local economic development in CBT perspective is defined as a process in which the local residents design, develop and implement the tourism development strategies by using local resources, with the aim to improve the quality of life and economic opportunity of the local community (Potter et al., 1999; Pike, Rodriguez \& Tomaney, 2006). Within the framework of local economic benefits and impacts, the benefits can be divided into direct effects and indirect effects. Direct effects towards the local economy are the effects, benefits, and consequences from the tourism activities themselves (Bowitz \& Ibenholt, 2009). These effects are generated through two main channels, which are earnings and revenues to the local community especially local-based businesses (Nel, 2001) as well as employment opportunities (Ashley, 2000; Wearver \& Lawton, 2007). According to UNWTO (2005), there are six ways in which the CBT may generate earnings and revenue for a particular local community: (1) the foreign exchange earnings, (2) direct and indirect employment and income, (3) ownership and management of tourism establishment (e.g. hotel, restaurants, café and private taxi), (4) direct sales of tourism goods and services to tourists, (5) investment in tourism infrastructure, and (6) development of cultural values.

CBT can boost the living standard of households with casual earnings and its propensity to generate equitable distribution of revenue (Ashley, 2000; Wearver \& Lawton (2007). Although the earnings are observed to be natural in most of the studies, it can be improved by diversifying the sources of earnings in the tourism sector. Recently, the numbers of small and medium enterprises (SMEs) in the tourism industry have increased due to the active involvement of the local communities in tourist destinations (Weaver \& Lawton, 2007). CBT provides direct employment to travel agents, hotel receptionists and food hawkers. Whereas, CBT indirect employment refers to employment in related sectors that do not serve the tourists directly but generates income from the expenditure in tourism linkages; for instance, the employees working in the construction industry building hotels (Ashley, 2000; Beeton, 2006; Tosun, 2006). Sebele (2010) describes that CBT can provide various sources of employment for the local communities as alternative means of survival (Nel, 2001).

Various sectors are connected to the tourism industry, such as accommodation, food and beverage, transportation, management, and health. The increase of goods and services demand from the tourists generates more 
PLANNING MALAYSIA

Journal of the Malaysia Institute of Planners (2017)

employment in handicraft making, agriculture, manufacturing and other related sectors. This is supported by Holloway (2000), who validated that tourism is a labour intensive industry generating many direct and indirect employment opportunities compared to other sectors.

From the previous broad discussions, CBT can be acknowledged as the community's long term tool for sustainability that preserves local resources and cultures, maintains the participation and support from community, and provides benefits to the local economy in terms of income, profits, jobs, and quality of life. However, one major drawback of the CBT concept is that detail study on economic impact and benefit of the community is still lacking as compared to studies on community participation in tourism development.

\section{Food and Beverage}

Cohen and Avieli (2004) believe that the food and beverage sector had been neglected in hospitality and tourism studies. This is due to the conventional view which stated that eating while traveling is a secondary tourists experience and routine (Godfrey \& Clarke, 2000; Quan \& Wang, 2004). However this finding is contradicted with published researches on food in relation to the tourism sector such as food experience in tourism (Kivela \& Crotts, 2006; Chang, Kivela \& Mak, 2011), local food consumption and spending (Torres, 2002; Kim et al., 2009), food service (Sheldon \& Fox, 1988; Nield, Kozak \& KeGrys, 2000), food as a form of special interest tourism (Hall et al., 2003; Long, 2004), as well as food preferences and choices among tourists (Torres, 2002; Chang, Kivela \& Mak, 2010).

On top of the aforementioned research, the tourist preference in food consumption has been discussed along with numerous factors, namely personality traits (Cohen \& Avieli, 2004; Quan \& Wang, 2004; Kim, Eves \& Scarles, 2009; Chang et al., 2011), exposure and past experience (Richards, 2002; Cohen \& Avieli, 2004; Ryu \& Jang, 2006) as well as physiology and motivation (Long, 2004; Kivela \& Crotts, 2006; Kim et al., 2009). In fact, studies have also confirmed that a number of socio-demographic factors have significantly influenced tourist expenditure, which among others are nationality and cultural influence. Tourists from Japan (Sheldon \& Fox, 1988), France, Italy (Pizam \& Sussman, 1995), South Korea, Taiwan and Thailand (March, 1997) have strong preferences for their own cuisine, while American and Canadian tourists prefer local food in the host destination (Torres, 2002). Cohen and Avieli (2004) confirm that Asian inbound tourists prefer their own national cuisine as compared to westerners who are less particular. In terms of age, it has been observed that younger tourists enjoy different tastes and range of foods compared to older tourists (Khan, 1981; Tse \& Crotts, 2005; Kim et al., 2009); whereas for gender, it has been observed that women are more interested in local cuisine compared to men (Kim et al., 2009). On the other hand, based on education level, it is found 
Syakir Amir, Mariana Mohamed Osman, Syahriah Bachok, Mansor Ibrahim, \& Ismawi Zen

Community-Based Tourism in Melaka UNESCO World Heritage Area: A Success in Food and Beverage Sector?

that tourists with higher education levels are more interested in experiencing foreign cultures by consuming the local cuisine (Khan, 1981; Kim et al., 2009).

\section{METHODOLOGY}

The diary record survey was implemented to record the expenses of domestic and international tourists that visited the study area with cluster sampling approach. This study employed the cluster sampling approach in the scope of probabilistic sampling method to collect the data. It has evenly distributed a total of 1,500 diary record survey booklets in selected hotels based on star-rating in Melaka. The hotels were divided into 3 main clusters. The first cluster consisted of 5 and 4 star hotels, the second cluster consisted of 3,2 and 1 star hotels, and third cluster consisted of budget hotels (3,2 and 1 orchard). Thus, each of the cluster was distributed with 500 diary records survey booklets, 250 booklets of which were distributed to domestic tourists while 250 booklets were distributed to inbound tourists. The survey was administered in two months (March and April) that included six weekdays and six weekends. The determination of survey period was based on the results of the two pilot studies; these two months recorded the highest tourists' peak in Melaka, for domestic and also inbound tourists. This was because the period being the peak of Malaysia's holiday season due to schoolbreak and spring holiday. Since the survey was a self-administered questionnaire, these booklets were distributed to the respondents during their hotel check-in at $2.00 \mathrm{pm}$. After completing the booklets, they returned them to the receptionist during check out at $12.00 \mathrm{pm}$. They reported their expenditure depending on the number of days spent in Melaka. For this study, Chi-square Automatic Interaction Detection (CHAID) analysis method was used to identify the linkages of tourist expenditure in several tourism sectors especially food and beverage. This method was established to involve continuous and categorical data that consists of ordinal and nominal types of variables. Hence, it is flexible in operate a mixture of data types. CHAID method have been successfully applied in many tourism and travel researches (Van Middlekoop, Borgers \& Timmermams, 2003; Assaker \& Hallak, 2012).

\section{RESULTS AND FINDINGS}

\section{Profile of Respondents}

1,500 sample were distributed for survey, but only 1,000 survey were collected. The survey collected 525 domestic respondents and 475 international respondents. From the initial cohort of domestic respondents, $39.0 \%$ were male and $13.5 \%$ were female, while from the total international respondents, $29.3 \%$ were male and $18.2 \%$ were female. Thus, the male respondents contributed towards $68.3 \%$ of the total responses and the female $31.7 \%$. Moreover, 21-30 years age group was recorded as the highest percentage (26.6\%) of domestic 
respondents participating in the survey, followed by 31-40 years age group (18.3\%), 11-20 years age group (3.4\%), 41-50 years age group (2.9\%), 51-60 years age group (10\%) and 61-70 years age group (3\%). Similarly, the 21-30 years age group was also recorded as the highest percentage (17.4\%) for international respondents, followed by 31-40 years age group (17.2\%), 41-50 years age group (6.4\%), 51-60 years age group (5.4\%) and 61-70 years age group (6\%). Respondents with single status was recorded as the highest percentage among domestic respondents, which was $28.8 \%$, followed by married $(23.3 \%)$, divorced/separated $(0.3 \%)$ and widowed $(0.1 \%)$; while married status was recorded as the highest percentage among international respondents, which was $23 \%$, followed by single $(22.6 \%)$, divorced/separated $(1.4 \%)$, and widowed $(0.5 \%)$.

Almost half (47.4\%) of those surveyed worked in the private sector with $19.4 \%$ were domestic respondents and $28 \%$ were international respondents. This followed by $22.4 \%$ that were government servants; $14 \%$ of which were among domestic respondents, and $8.4 \%$ were international respondents; $13.6 \%$ were selfemployed which comprised $9 \%$ domestic respondents and $4.6 \%$ international respondents; $12.3 \%$ were students comprising $9.5 \%$ domestic respondents and $2.8 \%$ international tourists; $3.9 \%$ were pensioners, which comprised $0.6 \%$ domestic tourists and $3.3 \%$ international respondents. $0.4 \%$ unemployed were recorded among international respondents. For education level, bachelor's degree was recorded as the highest percentage among domestic respondents (24\%), followed by diploma (12.7\%), master's degree (5.6\%), SPM/O-level (5.4\%), certificate (4.1\%), $\mathrm{PhD}(0.4 \%)$ and STPM/Matriculation/A-Level (0.3\%). Similarly, bachelor's degree was recorded as the highest percentage among international respondents at $31.4 \%$, followed by master's degree $(7.1 \%)$, diploma (3.9\%), certificate (2.1\%), $\mathrm{PhD}(1.7 \%), \quad$ SPM/O-level (0.8) and STPM/Matriculation/A-Level (0.4\%).

Of the initial cohort of 1,000 respondents, $83.5 \%$ visited Melaka for holiday purposes, where $45.5 \%$ of those were domestic respondents and $38 \%$ were international respondents. This was followed by business purposes $(6.5 \%)$, visiting family $(2.7 \%)$, education trip (2.5\%), shopping (1.9\%), conference/seminar (1.6\%) and health treatment purposes (1.3\%). Moreover, $36.9 \%$ of the international respondents visited Melaka for the first time compared to domestic respondents of only $8.1 \%$, while $44.4 \%$ of the domestic respondents had visited Melaka several times compared to only $10.6 \%$ international respondents. Next, in response to the number of visiting adults and children, $46 \%$ of the respondents were traveling single, while $85.2 \%$ travelled to Melaka without children. 
Syakir Amir, Mariana Mohamed Osman, Syahriah Bachok, Mansor Ibrahim, \& Ismawi Zen

Community-Based Tourism in Melaka UNESCO World Heritage Area: A Success in Food and Beverage Sector?

\section{Results of Tourists' Expenditure}

\begin{tabular}{|c|c|c|c|c|}
\hline Entertainment & Accommodation & Shopping & Transportation & $\begin{array}{l}\text { Food and } \\
\text { beverage }\end{array}$ \\
\hline $\begin{array}{c}\text { Tourist \%: } \\
61.6 \%\end{array}$ & $\begin{array}{c}\text { Tourist \%: } \\
45.0 \%\end{array}$ & $\begin{array}{c}\text { Tourist \%: } \\
29.9 \%\end{array}$ & $\begin{array}{c}\text { Tourist \%: } \\
26.0 \%\end{array}$ & $\begin{array}{c}\text { Tourist \%: } \\
22.1 \%\end{array}$ \\
\hline $\begin{array}{l}\text { Range: } \\
\text { RM 0.00 - } \\
\text { RM 6.25 }\end{array}$ & $\begin{array}{l}\text { Range: } \\
\text { RM 50 - } \\
\text { RM 464 }\end{array}$ & $\begin{array}{l}\text { Range: } \\
\text { RM 0- } \\
\text { RM 26.50 }\end{array}$ & $\begin{array}{l}\text { Range: } \\
\text { RM 0- } \\
\text { RM 13.50 }\end{array}$ & $\begin{array}{l}\text { Range: } \\
\text { RM 16.00- } \\
\text { RM } 147.50\end{array}$ \\
\hline
\end{tabular}

Figure 1 CHAID 1-Tourist Expenditure Linkage Generated by CHAID Source: Primary data: Diary record survey, March-April 2014

The tourists' expenditure linkage as illustrated in Figure 1 above was generated by Chi-Square Automatic Interaction Detection (CHAID) analysis for five tourism sectors. In order to identify tourist expenditure in the sectors, there was a need to observe the complete linkages that involve all terminal nodes (five tourism sectors) that created by CHAID analysis model. Secondly, each linkage was compared in terms of the number of tourists spending on each of the nodes (tourism sector) (Gacto, Alcala \& Herrera, 2010). Consequently, this will lead to the determination of the most effective linkage. Therefore, among the 29 linkages that created by CHAID analysis model, 'CHAID 1' as illustrated in figure above was recorded as the linkage with the highest number of respondents spending in the each tourism sectors as specified in the CHAID tree pattern. As a result, 'CHAID 1' was chosen as the main linkage to be evaluated in the second stage of the research process, which was to identify the local economic benefits. The decision was based on Janakow (1996) and Juang \& Chang (2010) that claim the linkage had the best performance and was the most prominent variable values in the CHAID tree pattern in which the linkage recorded with the highest number of respondents spending in the sectors. Therefore, $22.1 \%$ of the total respondents spent high percentage of expenses in the range of RM16-RM147.50 in food and beverage sector. This is parallel with the findings by Hall et al. (2003) that stated the food covers approximately one-third of all expenditure.

\section{Results of Local Economic Benefit}

Hajah Ruhana Restaurant, Hajah Mona Restaurant, Newton Food Court, Nyonya Resturant, San Shu Gong Restaurant, Famosa Chicken Rice Ball, Asam Pedas Selera Kampung, Asam Pedas Zahra Restaurant, Nasi Ayam Hoe Kee Restaurant, Jonker Street restaurants and cafés and Medan Selera in Medan Samudera were categorized as "local community'. On the other hand, Restaurants in Mahkota Parade, McDonalds, Hard Rock Café Melaka and Restaurants in Pahlawan Mall were categorized as 'non-local community'. Additionally, tourists that did not indicate any spending for meal was categorized as 'non-local community', as this category indicated less economic benefits for the local community. Tourists that 
PLANNING MALAYSIA

Journal of the Malaysia Institute of Planners (2017)

had meal outside the study area boundary, or had meal in relative's house or attended wedding were categorized as 'other'. This is because they were spending outside the boundary of the study area.

The validation and estimation of local involvement and ownership in the food and beverage sector was verified by the officer from Business Premises Management and Customer Service Department, Melaka Historic City Council.

\section{Breakfast}

Table 1 below illustrates the cross-tabulation result between 221 respondents and the food and beverage venues in which they have dined and spent between RM 16.00-RM 147.50 for breakfast. McDonald Café was recorded as the most popular dining venue among the respondents (14.5\%). It was followed by 12 respondents (5.4\%) spending at Restaurants in Mahkota Parade such as Nando's, The Chicken Rice Shop, Secret Recipe, Starbucks, Station Kopitiam, OldTown White Coffee, Kentucky Fried Chicken (KFC) and McDonalds. Only one respondent $(0.5 \%)$ each spending at Hajjah Ruhana Restaurant and Asam Pedas Zahra Restaurant at Plaza Mahkota. 155 respondents (70.1\%) provided 'no answer' for their breakfast record and thus was assumed that they did not have anything for breakfast.

Table 1 Summary of Cross-tabulation Result for Food and Beverage (Breakfast)

\begin{tabular}{lcc}
\hline Food and Beverage Venues & Percentage (\%) & Frequency (Person) \\
\hline Hotel & 0.9 & 2 \\
Jonker Street Cafes & 5.0 & 11 \\
McDonald Café & 14.5 & 32 \\
Mahkota Parade (Restaurants) & 5.4 & 12 \\
Hajjah Ruhana Restaurant & 0.5 & 1 \\
Asam Pedas Zahra Restaurant & 0.5 & 1 \\
Restaurant Melaka Raya (Mamak) & 1.8 & 4 \\
Kedai Kopi Chung Wah Jonker Street & 1.4 & 3 \\
'No answer' & 70.1 & 155 \\
\hline Total & $\mathbf{1 0 0 \%}$ & $\mathbf{2 2 1}$ \\
\hline
\end{tabular}

Source: Primary data: Diary record survey 
Syakir Amir, Mariana Mohamed Osman, Syahriah Bachok, Mansor Ibrahim, \& Ismawi Zen

Community-Based Tourism in Melaka UNESCO World Heritage Area: A Success in Food and Beverage Sector?

\section{Distribution of Local Economic Benefits (Food and Beverage: Breakfast)}

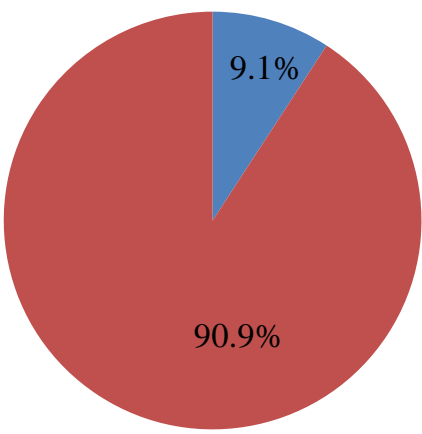

- Local community $\quad$ Non-local community

Figure 2 Distribution of Local Economic Benefits (Food and Beverage: Breakfast) Source: Primary data: Diary record survey, March-April 2015

Figure 2 above reveals the distribution of local economic benefits from the tourists' expenditure for breakfast in the food and beverage sector. Based on Figure 2 above, only $9.1 \%$ of the local community gained benefits from the food and beverage sector during breakfast in the study area, hence revealed the weak linkage between the food and beverage sector and the local community in the area. Moreover, the proportion for 'non-local community' was $90.9 \%$ during breakfast, which serves as an indication of the leakages occurring along the tourism value chain in the area.

\section{Lunch}

Table 2 and Figure 3 illustrate the cross-tabulation result between 221 respondents and the food and beverage venues in which they have spent between RM 16.00-RM 147.50 for lunch. Restaurants in Pahlawan Mall were recorded as the most popular dining place among tourists for lunch, as indicated by 43 respondents $(19.5 \%)$. It was followed by 36 respondents $(16.3 \%)$ spending at restaurants in Mahkota Parade. Asam Pedas Zahra Restaurant in Plaza Mahkota remains the least popular with only one respondent $(0.5 \%)$ had lunch there. One respondent $(0.5 \%)$ attending a wedding. 14 respondents $(6.3 \%)$ provided 'no answer' for their lunch expenditure and it was most probably that they skipped lunch. 
PLANNING MALAYSIA

Journal of the Malaysia Institute of Planners (2017)

Table 2 Summary of Cross-Tabulation Result for Food and Beverage (Lunch)

\begin{tabular}{lcc}
\hline & Percentage (\%) & $\begin{array}{c}\text { Frequency } \\
\text { (person) }\end{array}$ \\
\hline Hajjah Ruhana Restaurant (PM) & 2.3 & 5 \\
Asam Pedas Zahra Restaurant (PM) & 0.5 & 1 \\
San Shu Gong Restaurant (JS) & 2.7 & 6 \\
Nasi Ayam HoeKee (JS) & 1.4 & 3 \\
Famosa Chicken Rice Ball (JS) & 5.0 & 11 \\
Medan Selera Medan Samudera & 2.7 & 6 \\
Asam Pedas Selera Kampung & 0.9 & 2 \\
McDonald Cafe & 7.7 & 17 \\
Mahkota Parade (Restaurants) & 16.3 & 36 \\
Pahlawan Mall (Restaurants) & 19.5 & 43 \\
Jonker Street Restaurants and Cafes & 8.1 & 18 \\
Hard Rock Café Melaka & 9.5 & 21 \\
Wedding & 0.5 & 1 \\
Relatives house & 1.4 & 3 \\
Bukit Katil & 0.9 & 2 \\
Bukit Cina & 1.4 & 3 \\
Ayer Keroh & 8.1 & 18 \\
Jusco Aeon Peringgit & 5.0 & 11 \\
No answer & 6.3 & 14 \\
\hline Total & $\mathbf{1 0 0 \%}$ & $\mathbf{2 2 1}$ \\
\hline Source: Primary data: Diary record survey & &
\end{tabular}

Distribution of Local Economic Benefits (Food and Beverage: Lunch)

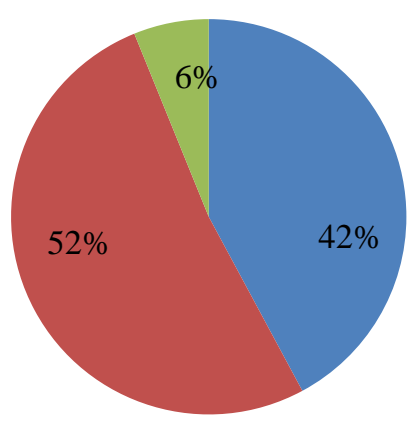

- Local community $\quad$ Non-local community $\quad$ Others

Figure 3 Distribution of Local Economic Benefits (Food and Beverage: Lunch) Source: Primary data: Diary record survey, March-April 2015 
Syakir Amir, Mariana Mohamed Osman, Syahriah Bachok, Mansor Ibrahim, \& Ismawi Zen

Community-Based Tourism in Melaka UNESCO World Heritage Area: A Success in Food and Beverage Sector?

Figure 3 presents the distribution of local economic benefits from the tourists' expenditure for lunch in the food and beverage sector. As can be seen, only $42 \%$ of the local community gained benefits from the food and beverage sector in the study area, hence revealed the weak linkage between the food and beverage sector and the local community in the area. Moreover, the proportion of economic gain for 'non-local community' was $58 \%$, which indicates where the leakages occur along the tourism value chain in the area.

\section{Dinner}

Table 3 and Figure 4 illustrate the cross-tabulation result between 221 respondents and food and beverage venues in which they have spent between RM16.00-RM147.50 for dinner. Hard Rock Café was recorded as the most popular dining place among respondents, as indicated by 36 respondents (16.3\%). It was followed by 32 respondents (14.5\%) spending at Hajah Mona Restaurant in Kota Laksamana and 30 respondents (13.6\%) spending at Banda Hilir McDonald Restaurant. The lowest response were two respondents $(0.9 \%)$ spending at Nyonya Restaurant and one respondent $(0.5 \%)$ spending at the hotel. 19 respondents $(8.6 \%)$ provided 'no answers' for their dining venue.

Table 3 Summary of Cross-tabulation Result for Food and Beverage (Dinner)

\begin{tabular}{lcc}
\hline Food and Beverage Venues & Percentage (\%) & Frequency (Person) \\
\hline Hard Rock Café Melaka & 18.6 & 41 \\
McDonald Café & 16.3 & 36 \\
Hajah Mona Asam Pedas & 8.1 & 18 \\
Jonker Street Restaurants and Cafes & 11.3 & 25 \\
Newton Food Court & 6.8 & 15 \\
Ikan Bakar Umbai & 10.0 & 22 \\
Mahkota Parade (Restaurants) & 10.4 & 23 \\
Pahlawan Mall (Restaurants) & 13.6 & 30 \\
Nyonya Restaurant Plaza Mahkota & 0.9 & 2 \\
Hotel & 0.5 & 1 \\
No answer & 3.6 & 8 \\
\hline Total & $\mathbf{1 0 0 \%}$ & $\mathbf{2 2 1}$
\end{tabular}




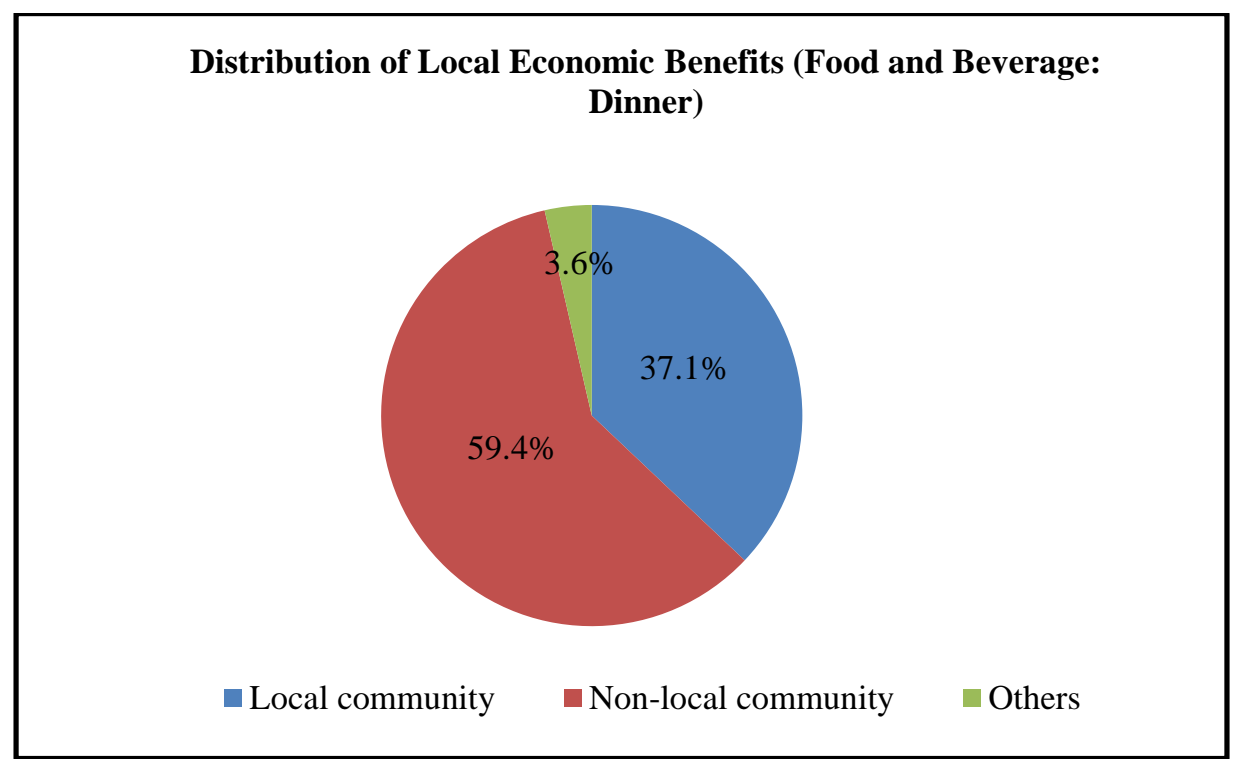

Figure 4 Distribution of Local Economic Benefits (Food and Beverage: Dinner) Source: Primary data: Diary record survey, March-April 2015

Figure 4 above reveals the distribution of local economic benefits from the tourists' expenditure for dinner in the food and beverage sector. Based on Figure 4, only $37.1 \%$ of the local community gained benefits from the food and beverage sector in the study area, hence revealed the weak linkage between the food and beverage sector and the local community in the area. The proportion of 'non-local community' benefits was $59.4 \%$, indicating where the leakages occur along the tourism value chain in the area.

\section{DISCUSSION}

According to the Value Chain Model developed, the food and beverage sector recorded high spending among domestic and inbound tourists, but provided low economic benefits to the local community in the Melaka UNESCO World Heritage area. As illustrated in CHAID linkage, $45 \%$ of the tourists spent in the range of RM16.00-RM147.50; and only 9.1\% from the tourists' expenditure was channelled to the local community during breakfast, $43.2 \%$ during lunch and $37.1 \%$ during dinner.

The high expenditure but low benefits to the local economy in terms of food and beverage in the study area could be attributed to a few factors. Firstly, the variety of unique local food in the study area attracts tourists due to the six major races with different religions found in the study area namely Malay, Chinese, Indian, Baba Nyonya (Chinese Peranakan), Chitty (Indian Peranakan), and Portuguese Serani, with their uniqueness and diversity of food. The authentic 
Syakir Amir, Mariana Mohamed Osman, Syahriah Bachok, Mansor Ibrahim, \& Ismawi Zen

Community-Based Tourism in Melaka UNESCO World Heritage Area: A Success in Food and Beverage Sector?

food in Melaka is associated with its historical roots, colonial influence, religion and local folk culture. By experiencing the local cuisines, the tourists are experiencing new cultures (Baker \& Crosbie, 1993). People nowadays have increased their experience to a variety of ethnic food and products during travel (Torres, 2002; Boxkir \& Sezer, 2011). Hence, this may encourage a greater demand for local cuisine. Food in the study area can be sampled everywhere and walking distance away (Nurbaidura Salim, Abdul Ghapar Othman, Badaruddin Mohamed \& Hairul Nizam Ismail, 2012), from luxury restaurants to local street stalls. Malay cuisines can be found in most places in the study area, which among others are Restoran Hajjah Mona Asam Pedas in Kota Laksamana and Asam Pedas Selera Kampung Restaurant in Plaza Mahkota, while Chinese cuisine is featured at the famous Hoe Kee Chicken Rice in Jonker Street. In addition, Baba Nyonya cuisine can be found at Bibik Neo Restaurant in Plaza Mahkota. In fact, most of the hotels in the study area actively advertise local traditional cuisine especially during the festive season. This gives them extra promotion to increase their occupancy.

Secondly, the experience of trying local food has encouraged the tourists to ignore the prices in order to enjoy the experience. In tourism, food consumption and expenditure are not referred to repetitive daily eating habits and routines. They are considered a request for various foods to engage in experiences. Quan \& Wang (2004) categorize two types of seeking behaviors in food consumption during holidays. First is routine rotation of various foods across time. This type of routine is known as "routine variety-seeking' behavior. Second is "noveltyseeking," or the act of eating foods that the tourists have never tried before. This refers to the tourists' behavior of requesting for food experiences that are beyond the borders of their routine. Sims (2009) categorises food experience as firstly, the ingredients of foods are unique and enjoyable; and secondly, the way the food is made, delivered and consumed is unique. This is described by the Hoe Kee Chicken Rice Restaurant, which is a famous Chinese restaurant among locals and tourists especially from Singapore and China. The restaurants situated in one of the small colonial shop lots located on Jalan Hang Jebat (Jonker Street). The crowd is apparent during the weekends. The signature dish, which is chicken rice that shaped like ping pong balls rather than served as a bowl of rice. This has created a new experience for tourists visiting Melaka, tasting the special chicken rice in a small local Chinese restaurant atmosphere. Food consumption during holidays might become part of the peak touristic experience (Quan \& Wang, 2004). Thus, these two factors have led to the increase in food consumption among tourists in Melaka, hence increasing the expenditure in the food and beverage sector. 
PLANNING MALAYSIA

Journal of the Malaysia Institute of Planners (2017)

In the context of the local economic benefits, the locally owned food outlets and restaurants have less demand from the tourists as compared to multinational operators. The spread of multinational operators in the food industry has given intense competition to the local food outlets. The food offered, including hamburgers, pizza, fried chicken, pastries, coffee, and ice-cream, attracts the young generation and children. Among the leading multinational operators and international companies are McDonalds, Hard Rock Café, KFC, Burger King, Baskin-Robbins, Domino's Pizza, Seoul Garden and Dunkin Donuts (Khan, 1981). These outlets can be found in the study area. On the other hand, locally owned food outlets encourage participation of the local community to produce, distribute and promote local products.

The local food operators do not have the ability and knowledge to promote their food as a tourism product. Many local restaurants and cafés in the study area are mostly small and medium-scaled. Most of the cafés on Jonker Street are family operated and only open at night or during weekends. Furthermore, they only provide a few tables and a small counter in front of the shop lot, with their homes at the back part of the shop. Hence, the desire to carry out promotion and awareness does not exist due to financial barriers, style of business and knowledge. In comparison, multinational companies and fast food enterprises such as McDonald and Hard Rock Café feature a distinct type of menu and target population. Therefore, Stout and Rust (1993), and Hyun, Kim and Lee (2011) believe that such big enterprises are controlling the specific segment of consumer market because of their promotion. Besides the strong promotion, they have strong world-recognized branding. The restaurant brand and labels affected the tourists' purchasing intentions (Albright \& Flora, 1990; McCall \& Lynn, 2008; Eibel et al., 2009). Therefore, the restaurants that have strong and wellknown label would dominate the local food options.

\section{CONCLUSION}

This paper has identified the local economic benefits from the tourists' expenses in food beverage sector. This study suggests strong partnerships or clustering among the tourism stakeholders, especially the suppliers in Melaka UNESCO World Heritage area. A cluster can be formed between similar tourism service suppliers and also between the suppliers that offer different kinds of tourism services to ensure that all the tourism products, services as well as facilities offered can be accessed by all kinds of tourists that visit the study area. For instance, the budget hotels in Jonker Street are encouraged to carry out a joint venture with the local restaurants nearby to provide breakfast to their overnight clients and deal with local traditional Malay massage parlours for discounts on their services. This is regularly applied in most tourism destinations such as Bali, Indonesia and Bangkok, Thailand. This partnership idea extremely promotes and supports local businesses, resulting in a stronger community because the money 
Syakir Amir, Mariana Mohamed Osman, Syahriah Bachok, Mansor Ibrahim, \& Ismawi Zen

Community-Based Tourism in Melaka UNESCO World Heritage Area: A Success in Food and Beverage Sector?

stays within the local area, hence promote the community-based tourism in Melaka. Moreover, the unique relationship among the local businesses may provide the community of the study area with a distinctive character and values that are currently lacking in the area. A suggestion of future research needs to be carried out to explore the factors affecting the poor and high participation and economic benefits in relation to Melaka UNESCO World Heritage site or other tourism destinations. The factors may include internal and external factors. It is important to note that not all tourism destinations operate and are impacted in the same way and to the same economic extent towards the local community. Some destinations may contribute more effectively towards the local economies.

\section{REFERENCES}

Aas, C., Ladkin, A., \& Fletcher, J. (2005). Stakeholder collaboration and heritage management. Annals of Tourism Research, 32(1), 28-48.

Albright, C. L., \& Flora, J. A. (1990). Restaurant menu labeling: Impact of nutrition information on entree sales and patron attitudes. Health Education, 17(2), 157-167.

Amat Ramsa Yaman, \& Abdullah Mohd. (2004). Community-based ecotourism: A new proposition for sustainable development and environmental conservation in Malaysia. Journal of Applied Sciences, 4(4), 583-589.

Ashley, C. (2000). The impacts of tourism on rural livelihoods: Experience in Namibia. ODI Working Paper 128, London: Overseas Development Institute.

Assaker, G., \& Hallak, R. (2012). European travelers' return likehood and satisfaction with Mediterranean sun-and-sand destinations: a chi-square automatic identification detector based segmentation approach. Journal of Vacation Marketing, 18(2), 105-120.

Baker, G. A., \& Crosbie, P. J. (1993). Measuring food safety preference: Identifying consumer segments. Journal of Agricultural and Resource Economics, 18(2), 2835 .

Beeton, S. (2006). Community Development through Tourism. Melbourne: Landlinks.

Bellamy, J., Meppem, T., Gorddard, R., \& Dawson, S. (2003). The changing face of regional governance for economic development: implications for local government. Sustaining Regions, 2(3), 7-17.

Bowitz, E., \& Ibenholt, K. (2009). Economic impacts of cultural heritage research and perspectives. Journal of Cultural Heritage, 10, 1-8.

Boxkir, A. S., \& Sezer, E, A. (2011). Predicting food demand in food courts by decision tree approaches. Procedia Computer Science, 3, 759-763.

Brandon, K. (1996). Ecotourism and conservation: A review of key issues. Washington: World Bank.

Chang, R. C. Y., Kivela, J., \& Mak, A. H. N. (2011). Attributes that influence the evaluation of travel dining experience: when east meets west. Tourism Management, 32 (2), 307-316.

Cohen, E., \& Avieli, N. (2004). Food in tourism: Attraction and impediment. Annals of Tourism Research, 31 (4), 755-778. 
Crompton, J. L., Lee, S., \& Shuster, T. J. (2001). A guide for undertaking economic impact studies: The springfest example. Journal of Travel Research, 40, 79-87.

Daniels, M. J., Norman, W. C., \& Henry, M. S. (2004). Estimating income effects of a sport tourism event. Annals of Tourism Research, 31 (1), 180-99.

Davis, J. S., \& Morais, D. B. (2004). Factions and enclaves: Small towns and socially unsustainable tourism development. Journal of Travel Research, 43(1), 3-10.

Eibel, B., Kersh, R., Brescoll, V., \& Dixon, B. (2009). Calorie labeling and food choices: A first look at the effects on low-income people in New York City. Health Affairs. 28(6), 1110-1121.

Fauziah Che Leh \& Mohd Rezuan Hamzah. (2012). Homestay tourism and pro-poor tourism strategy in Banghuris Selangor, Malaysia. Elixir International Journal, 45, 7602-7610.

Gacto, M. J., Alcalá, R., \& Herrera, F. (2010). Integration of an index to preserve the semantic interpretability in the multiobjective evolutionary rule selection and tuning of linguistic fuzzy systems. IEEE Transactions on Fuzzy Systems, 18(3), 515-531.

Godfrey, K., \& Clarke, J. (2000). The Tourism Development Handbook. Cassell, London.

Gunder, M. (2009). Imperatives of enjoyment: economic development under globalization. In J. E. Rowe (Ed.), Theories of local economic development: Linking theory to practice (pp. 285-300), Surrey, UK: Ashgate Publishing Limited.

Hollinshead, K. (2004). Symbolism in tourism: lessons from "Bali 2002": Lessons from Australia's dead heart. Tourism Analysis, 8, 267-295.

Holloway, J. (2000). Tour. In J. Jafari (Ed.), The Encyclopedia of tourism (pp.582-583), London: Routledge.

Hyun, S. S., Kim, W., \& Lee, M. J. (2011). The impact of advertising on patrons' emotional responses, perceived value and behavioral intentions in the chain restaurant industry: The moderating role of advertising-induced arousal. International Journal of Hospitality Management, 30, 689-700.

Jones, S. (2005). Community-based ecotourism: The significance of social capital. Annals of Tourism Research, 32 (2), 303-24.

Kasimati, E. (2003). Economic aspects and the summer Olympics: A review of related research. International Journal of Tourism Research, 5, 433-444.

Khan, M. A. (1981). Evaluation of food selection patterns and preferences. CRC Critical Reviews in Food Science and Nutrition, 15, 129-153.

Kim, Y. G., Eves, A., \& Scarles, C. (2009). Building a model of local food consumption on trips and holidays: A grounded theory approach. International Journal of Hospitality Management, 28, 423-431.

Kivela, J., \& Crotts, J.C. (2006). Tourism and gastronomy: Gastronomy's influence on how tourists experience a destination. Journal of Hospitality and Tourism Research, 30 (3), 354-377.

Kling, J. M., \& Posner, P. S. (1990). Class and community in an era of urban transformation. In J. M. Kling \& P. S. Posner (Eds.). Dilemmas of activism: Class, community, and the politics of local mobilization (pp. 23-45). Philadelphia: Temple University Press.

Koo, J. (2005). Technology spillovers, agglomeration, and regional economic development. Journal of Planning Literature, 20(2), 99-115. 
Syakir Amir, Mariana Mohamed Osman, Syahriah Bachok, Mansor Ibrahim, \& Ismawi Zen

Community-Based Tourism in Melaka UNESCO World Heritage Area: A Success in Food and Beverage Sector?

Lee, T. H. (2012). Influence analysis of community resident support for sustainable tourism development. Tourism Management, 34, 37-46.

Lepp, A. (2007). Residents' attitudes towards tourism in Bigodi village, Uganda. Tourism Management, 28(3), 876-885.

Li, G., Song, H., \& Witt, S. F. (2005). Recent developments in econometric modeling and forecasting. Journal of Travel Research, 44(1), 82-99.

Long, L. M. (2004). Culinary Tourism. Kentucky: The University Press of Kentucky.

Madrigal, R. (1995). Residents' perceptions and the role of government. Annals of Tourism Research, 22(1), 86-102.

Mayer, L. C., Burnett, J. H., Ogden, S., \& Tuman, J. P. (2000). Comparative politics: Nations and theories in a changing world. New Jersey: Prentice.

McCall, M., \& Lynn, A. (2008). The effects of restaurant menu item descriptions on perceptions of quality, price ad purchase intention. Journal of Foodservice Business Research, 11(4), 439-445.

McCool, S. F., Moisey, R. N., \& Nickerson, N. P. (2001). What should tourism sustain? The disconnect with industry perceptions of useful indicators. Journal of Travel Research, 40(4), 124-131.

McMillan, D. W., \& Chavis, D. M. (1986). Sense of community: A definition and theory. Journal of Community Psychology. 14, 6-23.

Mihalic, T. (2002). Tourism and economic development issues. In R. Sharpley \& D. J. Telfer (Eds.), Tourism and development: Concepts and issues (pp. 81-111). Clevedon, UK: Channel View Publications.

Mok, C., \& Iverson, T. J. (2000). Expenditure based segmentation: Taiwanese tourists to Guam. Tourism Management, 21(3), 299-305.

Nel, E. (2001). Local economic development: A review and assessment of its current status in South Africa. Urban Studies, 38(7), 1003-1024.

Nield, K., Kozak, M., \& LeGrys, G., (2000). The role of food service in tourist satisfaction. International Journal of Hospitality Management, 19, 375-384.

Nurbaidura Salim, Abdul Ghapar Othman, Badaruddin Mohamed, \& Hairul Nizam Ismail. (2012). Heritage awareness among tour operators in heritage sites: A case study of rickshaw pullers in Melaka. Paper presented at $3^{\text {rd }}$ International Conference on Business and Economic Research, March 12-13, Bandung, Indonesia.

Pearce, P. L., \& Moscardo, G. (1999). Tourism community analysis: Asking the right questions. In D. G. Pearce \& R. W. Butler (Eds.). Contemporary issues in tourism development (pp. 31-51). London and New York: Routledge.

Pike, A., Rodriguez, P. A., \& Tomaney, J. (2006). Local and Regional Development. New York: Routledge.

Potter, J., Walsh, J., De Varine, H., \& Barreiro, F. (1999). Best practices in local development. Local Employment and Economic Development Programme, OECD-TDS, Paris.

Quan, S., \& Wang, N. (2004). Towards a structural model of the tourist experience: An illustration from food experience in tourism. Tourism Management, 25 (3), 297 305 . 
Roe, D., Ashley, C., Page, S., \& Meyer, D. (2004). Tourism and the poor: Analysing and interpreting tourism statistics from a poverty perspectives (Working paper No. 16). London: UK Department for International Development. .

Rowe, J. E. (2009). Moving the theory of local economic development beyond metaphors. Australasian Journal of Regional Studies, 15(1), 101-114.

Rowe, J. E. (2012). The case for employing Deleuzian philosophical concepts for understanding local economic development. Applied Geography, 32, 73-79.

Scott, A. J. (2006). Creative cities: Conceptual issues and policy questions. Journal of Urban Affairs, 28(1), 1-17.

Sebele, L. S. (2010). Community based tourism ventures, benefits and challenges: Khama Rhino Sanctuary Trust, Central District, Botswana. Tourism Management, 31, 136-146.

Shaffer, R., Deller, S., \& Marcouiller, D. (2006). Rethinking community economic development. Economic Development Quarterly, 20(1), 59-74.

Sheldon, P., \& Fox, M. (1988). The role of foodservice in vacation choice and experience: A cross-cultural analysis. Journal of Travel Research, 27 (3), 9-15.

Song, H., \& Li, G. (2008). Tourism demand modelling and forecasting: A review of recent research. Tourism Management, 29(2), 203-220.

Stout, P. A., \& Rust, R. T. (1993). Emotional feelings and evaluative dimensions of advertising: Are they related? Journal of Advertising, 22(1), 61-72.

Sutawa, G. K. (2012). Issues on Bali tourism development and community empowerment to support sustainable tourism development. Procedia Economics and Finance, 4, 413-422.

Torres, R. (2002). Toward a better understanding of tourism and agriculture linkages in the Yucatan: Tourist food consumption and preferences. Tourism Geographies, 4 (3), 282-306.

Tosun, C. (2000). Limits to community participation in the tourism development process in developing countries. Tourism Management, 21, 613-633.

Trejos, B., \& Chiang, L. H. N. (2009). Local economic linkages to community-based tourism in rural Costa Rica. Singapore Journal of Tropical Geography, 30, 373 387.

Tyrrell, T. J., \& Johnston, R. J. (2001). A framework for assessing direct economic impacts of tourist events: Distinguishing origins, destinations, and causes of expenditures. Journal of Travel Research, 40, 94-100.

Valler, D., \& Wood, A. (2010). Conceptualizing local and regional economic development in the USA. Regional Studies, 44(2), 138-151.

Van Middlekoop, M., Borgers, A., \& Timmermans, H. (2003). Inducing heuristic principles of tourist choice of travel mode: A rule based approach. Journal of Travel Research, 42(1), 75-83.

Wang, Y., Rompf, P., Severt, D., \& Peerapatdit, N. (2006). Examining and identifying the determinants of travel expenditure patterns. International Journal of Tourism Research, 8(5), 333-346.

Weaver, D. B., \& Lawton, L. J. (2007). Twenty years on the state of contemporary ecotourism research. Tourism Management, 28, 1168-1179.

Wells, M. P. (1996). The social role of protected areas in the new South Africa. Environment Conservation, 23(4), 322-331. 
Syakir Amir, Mariana Mohamed Osman, Syahriah Bachok, Mansor Ibrahim, \& Ismawi Zen

Community-Based Tourism in Melaka UNESCO World Heritage Area: A Success in Food and Beverage Sector?

Williams, J., \& Lawson, R. (2001). Community issues and resident opinions of tourism. Annals of Tourism Research, 28(2), 269-290.

Zaaijer, M., \& Sara, L. M. (1993). Local economic development as an instrument for urban poverty alleviation: A case from Lima, Peru. Third World Planning Review, $15,127-142$. 